\title{
FBX038 Gene
}

National Cancer Institute

\section{Source}

National Cancer Institute. FBXO38 Gene. NCI Thesaurus. Code C114610.

This gene may play a role in protein ubiquitination. 